\title{
BARDAISAN'S INFLUENCE ON LATE ANTIQUE CHRISTIANITY
}

\author{
UTE POSSEKEL \\ HARVARD DIVINITY SCHOOL
}

\begin{abstract}
This article seeks to evaluate how the thought of Bardaisan of Edessa was received by later generations of Christians. The article shows that the Book of the Laws of Countries, a Syriac dialogue in which Bardaisan is the main interlocutor, exercised considerable influence in both the Greek- and Syriac-speaking worlds. Although later authors tended to denigrate Bardaisan's views on fate and free will as an undue compromise, they nevertheless did not hesitate to borrow freely from his cogent antideterministic arguments and integrate them into their own discourses. But Bardaisan's influence, especially in the Syriacspeaking regions, extended into other areas as well: his innovations in the realm of poetry and music, his astronomical calculations, his ethnographic discourse, and his anti-Marcionite polemics were all appreciated and adapted by subsequent authors. While it is well known that later Christians tended to malign Bardaisan's thought, and especially his cosmology, as tainted with heresy, this article favors a more nuanced view: alongside the late antique rejection of Bardaisan runs a notable current of positive reception of his innovative contributions in the realms of science, music, and apologetics.
\end{abstract}


Bardaisan (154-222) composed numerous works on a wide array of theological and philosophical topics, ranging from cosmology to eschatology, from ethnographic surveys to astronomy. ${ }^{1}$ Yet of his large literary output nothing has been preserved in its entirety save the Syriac dialogue known as the Book of the Laws of the Countries, written down by Bardaisan's disciple Philip, in which Bardaisan is the main interlocutor. ${ }^{2}$ The fact that only this was preserved by later generations of Christians is already indicative of its impact upon the late antique church. Yet while Bardaisan's reflections on free will and fate, as set down in this dialogue, evidently had a long trajectory of influence upon both Syriac and Greek-speaking readers, upon closer inspection it emerges that other aspects of his teachings did so as well. This essay will highlight some areas in which Bardaisan's oeuvre shaped and challenged subsequent generations of Christians.

${ }^{1}$ EUSEBIUS mentions dialogues composed by Bardaisan against the Marcionites and other heretics, as well as a dialogue On Fate (h.e. 4.30.1, ed. E. Schwartz / Th. Mommsen, Eusebius, Werke II.1. Die Kirchengeschichte, second edition, GCS N.F. 6,1 (Berlin 1999), 392,15-17.21-22). EPHREM

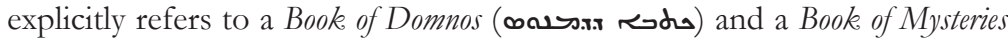
(مוri (סook of Domnos: EPHREM, Prose Refutations (hereafter cited as PR), ed. with Engl. transl. C. W. MitChelL / A. A. BEvan / F. C. BuRKITT, S. Ephraim's Prose Refutations of Mani, Marcion, and Bardaisan, 2 vols. (London 1912-1921), vol. 2, p. 1 and p. 6,42-43; Book of Mysteries: EPHREM, Hymns against Heresies 56,9, ed. with German transl. E. BECK, Ephraem des Syrers Hymnen contra haereses, CSCO 169-170 /Syr. 76-77 (Louvain 1957) (hereafter cited as $\mathrm{CH}$ ), text in CSCO 169, 211,22; cf. CH 1,14 (ed. Beck, $4,11)$. He also notes that Bardaisan composed hymns (CH 53,5-6, ed. Beck, 203,5-14), and a treatise on the resurrection (Hymns on Nisibis 51,2-3, ed. with German transl. E. BECK, Des heiligen Ephraem des Syrers Carmina Nisibena, CSCO 218-219 / Syr. 92-93 [Louvain 1961-1963]). Bardaisan also wrote on astronomical subjects and composed a treatise on India (on these, see below).

2 The Book of the Laws is preserved in only one manuscript, BL Syr. add. 14658, fol. 129a-141a, dated by Wright to the seventh century (W. Wright, Catalogue of the Syriac Manuscripts in the British Museum, vol. 3 [London 1872], 1154). This manuscript contains various treatises of philosophical and scientific content (see ibid., 1154-1160). 


\section{THE MEMORY OF BARDAISAN}

Before addressing particular aspects of Bardaisan's Wirkungsgeschichte, it will be convenient to trace how the memory of Bardaisan as a person was preserved in Greek, Latin, Syriac, and Arabic literature. ${ }^{3}$ Although his writings were lost, his remembrance was kept alive by friend and foe alike. ${ }^{4}$ Considering the fierce polemics of later Syriac authors, it comes as a surprise to note that many of those late antique writers who mention him express rather an amicable attitude towards the Edessene theologian. Amongst those who expressly value Bardaisan are Julius Africanus (who left the only historical account of a personal encounter with Bardaisan), Eusebius of Caesarea, Didymus the Blind, the anonymous fourth-century author of the Life of Aberkios, and Jerome. ${ }^{5}$ Even Epiphanius, in spite of his objec-

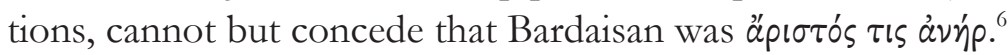

${ }^{3}$ For reasons of space, the Armenian tradition cannot be considered here.

${ }^{4}$ The (in his view irreconcilable) discrepancies in the reception history of Bardaisan in late antiquity were emphasized by the Dutch scholar T. Jansma, Natuur, lot en vrijheid. Bardesanes, de filosoof der Arameërs en zijn images, Cahiers bij het Nederlands theologisch tijdschrift 6 (Wageningen 1969).

5 Julius Africanus, Kestoi 7.20, ed. and transl. M. Wallraff / C. Scardino / L. Mecella / Ch. Guignard / W. Adler, Cesti: The Extant Fragments, GCS N.F. 18 (Berlin 2012), 98-103; EuSEBIUS, h.e. 4.30.1, ed. SCHWARTZ / MOMMSEN, 392,15-17.21-22 (praises Bardaisan's ingenuity); DidyMus the BLIND, Commentary on Psalms 181,8-9 (on Ps. 32), ed. with German transl. A. GeSCHÉ / M. GronewALD, Didymus der Blinde, Psalmenkommentar (Tura-Papyrus), vol. 3, Papyrologische Texte und Abhandlungen 8 (Bonn 1969), 182-184 (discusses Bardaisan without a negative comment); Life of Aberkios, ed. Th. Nissen, S. Abercii Vita (Leipzig 1912); Jerome, Vir. ill. 33, ed. E. C. RiCHARDSON, Hieronymus, Liber de viris inlustribus. Gennadius, Liber de viris inlustribus, TU 14.1 (Leipzig 1896), 24-25.

${ }^{6}$ Ephiphanius, Pan. 56.1.2, ed. K. Holl, Epiphanius, Werke II, GCS (Leipzig 1922), 338,5. English transl. F. Williams, The Panarion of Epiphanius. Books II and III (Sects 47-80, De Fide), Nag Hammadi and Manichaean Studies 36 (Leiden 1994). 
Although several of these authors express some doubt regarding Bardaisan's orthodoxy - based, of course, on their own later theological perspectives - they all articulate their admiration for the man: his learning, his eloquence, his refutation of heresy, his skill as an archer, his scientific mindset.

Over against this group of predominantly Greek-speaking authors favorably disposed towards the Edessene stand those with a hostile attitude, most of whom flourished in the same Syriac milieu as did Bardaisan. His most outspoken critic was the poet Ephrem (d. 373), yet even he does not hesitate occasionally to borrow from Bardaisan's ideas - without acknowledgement, to be sure. Eusebius of Emesa (d. ca. 359), who grew up bilingually in Edessa and wrote in Greek, engages with Bardaisan's views in his Commentary on Genesis. ${ }^{7}$ Significantly, the only two non-biblical authors mentioned by name in this commentary are Bardaisan and Homer. ${ }^{8}$ In the course of the christological controversies of the fifth and sixth centuries, associating one's opponent with Bardaisan and his theology became a convenient rhetorical tool, but here, too, authors sometimes unintentionally cited passages from Bardaisan's works that seem to have become part of the common lore. ' A negative memory of Bardaisan is preserved in the heresiological

7 The commentary is preserved only in an Armenian version and in Greek and Syriac fragments, ed. F. PETIT / L. VAN ROMPAY / J. J. S. WEITENBERG, Eusèbe d'Émèse, Commentaire de la Genèse. Texte arménien de l'édition de Venise (1980). Fragments grecs et syriaques. Avec traductions, Traditio Exegetica Graeca 15 (Louvain 2011); section on Bardaisan on pp. 92-95, 212-215, 292-295. See also R. B. TER HAAR Romeny, A Syrian in Greek Dress. The Use of Greek, Hebrew, and Syriac Biblical Texts in Eusebius of Emesa's Commentary on Genesis, Traditio Exegetica Graeca 6 (Louvain 1997), 265-271. Space does not suffice here to discuss to what extent the opinions attributed to Bardaisan by Eusebius of Emesa reflects Bardaisan's own thought, and to what extent they may represent either later developments among his disciples or heresiological attempts to discredit Bardaisan.

8 Petit / VAn Rompay / WeITENBERG, Eusèbe d'Émèse, xxxviii, note 69.

9 Cf. L. VAN Rompay, "Bardaisan and Mani in Philoxenus of Mabbog's Mèmrē Against Habbib," in: Syriac Polemics. Studies in Honour of Gerrit 
summaries of a much later age, including those by Barhadbeshabba 'Arbaia (6 ${ }^{\text {th }}$ cent.), Theodore bar Koni (late $8^{\text {th }}$ cent.), Moses bar Kepha (d. 903), and Michael the Syrian $\left(12^{\text {th }}\right.$ cent $) .{ }^{10}$ On the other hand, some later Syriac authors do express a favorable attitude towards Bardaisan, namely with regard to his scientific understanding of astronomy.

One reason for this surprising disparate reception within the Greek and Syriac traditions is that fact that in the Syriacspeaking communities of northern Mesopotamia Bardaisanite teachings long continued to be a force to be reckoned with, challenging the established church with doctrines at times much more radical than had been those of Bardaisan himself. Another, and not entirely unconnected reason for this disjunct memory of Bardaisan is that in the Syriac tradition Bardaisan's name primarily remained associated with his cosmology (later judged to be heretical), whereas Christians in territories to the West of Edessa remembered Bardaisan principally for his capable refutation of astral determinism.

A third and distinct memory of Bardaisan is preserved by later Arabic-speaking authors, many of whom regard him as a

Jan Reinink, ed. W. J. V. BeKKuM / J. W. Drijvers / A. C. KLUGKIST, OLA 170 (Louvain 2007), 77-90.

10 BarHadBeshabBa 'ARBAia, History 2.5, ed. F. NAU, La première partie de l' Histoire de Barbadbešabba 'Arbaïa. Texte syriaque édité et traduit, PO 23.2 (1932), 191-192; THEODORE BAR KONI, Scholion 11.49, ed. A. SCHER, Theodorus bar Kōni, Liber scholiorum II, CSCO 69 / Syr. 26 (Louvain 1954), 307,20-308,20; French transl. R. HesPeL / R. DRAGUET, Théodore bar Koni, Livre des scolies (recension de Séert), CSCO 432 / Syr. 188 (Louvain 1982), 229f.; MOSES BAR KePHA, Hexaemeron Commentary 1.14, relevant section ed. F. NAU, Patrologia Syriaca 1.2 (1907), 513-514; section also ed. H. J. W. Drijvers, Bardaisan of Edessa, Studia Semitica Neerlandica 6 (Assen 1966), 98-104; German transl. of the entire treatise L. SCHLIMME, Der Hexaemeronkommentar des Moses bar Kepha. Einleitung, Übersetzung und Untersuchungen, 2 vols., Göttinger Orientforschungen, 1. Reihe: Syriaca, vol. 14.1-2 (Wiesbaden 1977), passage on Bardaisan in vol. 1, 137-140; Michael the Syrian, Chronicle, ed. with French transl. J.-B. CHABOT, Chronique de Michel le Syrien, 4 vols. (Paris 1899-1910, reprint Brussels 1963), vol. 1, 183-185 (transl.), vol. 4, 109-111 (text). 
dualist (which he was not) and attribute to him otherwise unknown (and most likely inauthentic) works. Ibn al-Nadim, for instance, lists three book titles for Bardaisan that are unknown in the Syriac tradition. ${ }^{11}$ By and large, the Arabic testimonies to Bardaisan reflect much later concerns with dualist sects and fall outside the scope of this essay. ${ }^{12}$

\section{FATE AND FREE WILL}

Bardaisan's refutation of astral determinism, as expressed in the Book of the Laws, has had the most obvious impact upon late antique Christianity. This is the only work preserved in its entirety, and it is also the one cited most widely - with or without attribution to Bardaisan - in the patristic literature. The Syriac dialogue has come down to us in a seventh-century manuscript, thus it was still read and copied at that time. ${ }^{13}$ Both

${ }^{11}$ IBN AL-NADIM, Fibrist 9.1, ed. G. FLÜGEL, Kitab al-Fibrist, 2 vols. (Leipzig 1871-1872); transl. B. DoDGE, The Fibrist of al-Nadim. A Tenth-Century Survey of Muslim Culture, 2 vols. (New York 1970), vol. 2, 805f. Al-Nadim mentions a Book of Light and Darkness, a Book of the Spirituality of the Truth, and a Book of the Moving and the Static.

${ }^{12}$ Important references to the Bardaisanites by Arabic authors can be found in the writings of al-Nadim, al-Warraq, al-Maturidi, and al-Biruni. Some of these are translated and discussed in the following publications: G. VAJDA, "Le témoigne de al-Māturidī sur la doctrine des Manichéens, des Dayṣānites et des Marcionites," Arabica 13 (1966), 1-38; W. MADELUnG, "Abū 'Īsā al-Warrāq über die Bardesaniten, Marcioniten und Kantäer," in: Studien zur Geschicbte und Kultur des Vorderen Orients. Festschrift für Bertold Spuler zum siebzigsten Geburtstag, ed. H. R. ROEMER / A. NOTH (Leiden 1981), 210224; G. Monnot, Islam et religions, Islam d'hier et d'aujourd'hui 27 (Paris 1986), 34-37, 167-168; J. VAN Ess, Theologie und Gesellschaft im 2. und 3. Jabrbundert Hidschra. Eine Geschicbte des religiösen Denkens im frühen Islam, 6 vols. (Berlin 1991-1995), vol. 1 (1991), 426-430 (with further bibliography).

${ }^{13}$ Detailed discussion of the manuscript's content and its possible Sitz in Leben as a school curriculum may be found in D. KING, "Origenism in Sixth Century Syria: The Case of a Syriac Manuscript on Pagan Philosophy," in Origenes und sein Erbe in Orient und Okzident, edited by A. FÜRST (Münster 2011), 179-212. King's assertion, however, that this collection represents Origenist teachings (see esp. 208-211; elsewhere in the article the subject of Origenism is hardly mentioned) is not wholly convincing. 
Greek and Syriac-speaking Christians would have been familiar with Bardaisan's thought also through reading Eusebius' Ecclesiastical History, the Syriac version of which likely dates from the fourth century. ${ }^{14}$

Several early Syriac treatises, such as the Apology of Ps.Melito or the Acts of Thomas, ${ }^{15}$ contain passages that show close affinities with the Book of the Laws. This might suggest, as some scholars have posited, ${ }^{16}$ that the respective authors of these treatises were familiar with the Syriac dialogue, but only a close textual analysis can ascertain whether such similarities are not better explained by the authors' common cultural and intellectual milieu.

Ephrem the Syrian in the fourth century was confronted, much like Bardaisan was in the early third, with deep-seated astrological beliefs among members of his community. In his Hymns against Heresies, the poet specifically targets his congregants' misguided trust in horoscopes and fate, and at times Ephrem's arguments are reminiscent of those set forth in the Book of the Laws so that a familiarity with Bardaisan's most important work appears likely. Bardaisan in the dialogue asserts that fate does not control human free will in ethical matters, nor does it determine natural processes such as bodily growth

14 The Syriac version of Eusebius' Ecclesiastical History is ed. W. WRIGHT / N. MCLEAN, The Ecclesiastical History of Eusebius in Syriac, edited from the manuscripts. With a collation of the ancient Armenian version by Adalbert Merx (Cambridge 1898), the section on Bardaisan is on p. 243f. The Syriac version of the Ecclesiastical History is extant in several manuscripts; on these, see A. BAUMSTARK, Geschichte der syrischen Literatur mit Ausschluß der christlichpalästinensischen Texte (Bonn 1922), 58-59.

15 Ps.-Melito, Apology, ed. W. CurETON, Spicilegium Syriacum: containing remains of Bardesan, Meliton, Ambrose and Mara bar Serapion (London 1855), 21-31 (text), 41-51 (transl.). Space does not permit here a discussion of the relation between the BLC and Ps.-Melito's Apology and the Acts of Thomas, respectively.

${ }^{16}$ I. RAMELLI, Bardaisan of Edessa. A Reassessment of the Evidence and a New Interpretation (Piscataway, NJ 2009), 111-114, maintains the Acts of Thomas "include an unequivocal quotation" from the Book of the Laws (p. 111). 
or the need for nourishment. Prominent among Bardaisan's examples in support of his claim that fate does not have power over nature, is that not before puberty or in old age are people able to conceive children, regardless of fate. ${ }^{17}$ In his hymns, Ephrem employs a very similar rationale to oppose the view that fate is responsible for sexual transgressions, for that would imply that only during a certain age does fate have this power. ${ }^{18}$ Moreover, Ephrem brings forth several extensive objections to the claim, articulated in the Book of the Laws, that fate is the cause of sickness, health, or a person's social status. ${ }^{19}$ Taken alone, any of these arguments would not suffice to establish Ephrem's familiarity with the Syriac dialogue, but in their entirety they would seem to allow no conclusion other than that Ephrem was well aware of the book's content.

Bardaisan's rebuttal of astral determinism was still well remembered and appreciated among learned Syriac authors in the early eighth century, for Jacob of Edessa (d. 708) favorably comments on the Bardaisanite refutation of fate in his Commentary on the Hexaemeron. In this remarkable passage, Jacob recalls how a man from Edessa, who belonged to the school of Bardaisan, capably refuted the astral determinism advocated by an astrologer from Harran. ${ }^{20}$

Turning to the reception history of Bardaisan's Book of the Laws in Greek patristic literature, it becomes apparent that here, unlike among Syriac authors, Bardaisan's authorship is generally much more readily acknowledged. Eusebius records in his Ecclesiastical History that Bardaisan's disciples translated

${ }^{17}$ BLC 20, ed. NAU, 572,1-575,3. On Bardaisan's defense of free will against astral determinism, see for example T. HEGEDUs, Early Christianity and Ancient Astrology (New York 2007), 261-278.

18 EPHrEm, CH 4,15, ed. Beck, 17,9-14. In CH 6,12-13, ed. Beck, 25,25-26,10, he mentions the example of old age.

19 Ephrem, CH 4,8-11.14; 5,4.9-10; 6,2.6 and passim, ed. Beck, 15,22-16,18; 17,3-8; 19,11-16; 20,13-24; 23,15-20; 24,16-21.

${ }^{20} \mathrm{JACOB}$ OF EDESSA, Hexaemeron, ed. I.-B. CHABOT, Iacobi Edesseni Hexaemeron, CSCO 92 / Syr. 44 (Louvain 1953), 61a,35-62a,24. Jacob even knows the name of the Bardaisanite: Vologeses. 
his dialogues from Syriac into Greek, ${ }^{21}$ and we may assume that the Book of the Laws was among these treatises so that the dialogue would have been available to Greek readers from a very early time.

A long excerpt from the Book of the Laws is contained in the Ps.-Clementine Recognitions, a fascinating novel produced in fourth-century Syria that extensively reworks earlier materials. In the Recognitions Clement of Rome recounts in the first person his conversion to Christianity, his adventurous journeys with Peter the apostle, and his eventual reunification with his (now likewise converted) family. ${ }^{22}$ The book includes also lively conversations between the chief protagonists and prolonged theological discourses. In book nine, Clement debates with a defender of astrological fate, and Clement's counter-arguments here include of a long section lifted from the second part of the Book of the Laws (25-46), without, however, naming either Bardaisan or Philip. ${ }^{23}$ Although parts of the Recognitions survive in a Syriac translation of the Greek original, ${ }^{24}$ the relevant passage is extant only in the Latin version of Rufinus and shows a number of deviations from the Syriac text of the Book of the Laws. The encounter between Clement and the defender of astrology (who in the end turns out to be Clement's father) is narrated in the Ps.-Clementine Homilies as well, although here

${ }^{21}$ Eusebius, h.e. 4.30.1, ed. Schwartz / Mommsen, 392,19-21.

22 Ps.-Clementine Recognitions, ed. B. ReHm / G. STRECKER, Die Pseudoklementinen II: Rekognitionen in Rufins Übersetzung, second edition, GCS (Berlin 1994); English transl. T. SMITH, ANF 8 (reprint 1989), 73-211.

23 Ps.-Clementine Rec. 9.19-29, ed. REHM / STRECKER, 270-314. BLC 25-46, ed. NAU, 582,5-608,13.

${ }^{24}$ A Syriac translation of portions from the Ps.-Clementines is contained in the famous manuscript BL Syr. add. 12150, dated to AD 411 and thereby the oldest dated Syriac manuscript. Ed. of the Syriac in W. FRANKENBERG, Die syrischen Clementinen mit griechischem Paralleltext, TU 48/3 (Leipzig 1937). English transl. F. S. JONES, The Syriac Pseudo-Clementines. An Early Version of the First Christian Novel (Turnhout 2014). 
the section from the Book of the Laws is wanting. ${ }^{25}$ The great number of parallels between the Recognitions and Homilies has led scholars to postulate the existence of a Ps.-Clementine Grundschrift (dated to between 220 and 260), and this Grundschrift already would have included the sections from Bardaisan's dialogue. ${ }^{26}$ The Ps.-Clementines thus contain the oldest known quotation from the Book of the Laws.

The earliest Greek author explicitly to attribute quotations from the dialogue on fate to Bardaisan is Eusebius, who in his Praeparatio evangelica excerpts lengthy passages. ${ }^{27}$ The church historian remarks that he quotes from Bardaisan's dialogues with his companions, but he does not specify a title. The sections cited by Eusebius are almost the same as those quoted in the Ps.-Clementine Recognitions, ${ }^{28}$ a fact that has given rise to an extensive scholarly debate concerning the original language of the Book of the Laws and the various intertextual dependencies between the Syriac dialogue, Eusebius, and the Ps.-Clementine Recognitions. ${ }^{29}$ Whereas in his Ecclesiastical History Eusebius acknowledges Bardaisan's contribution to Christian theological

25 Ps.-Clementine Hom. 14, ed. B. ReHM / G. STRECKER, Die Pseudoklementinen I. Homilien, third edition, GCS (Berlin 1992), 204-211.

${ }^{26}$ B. REHM, "Bardesanes in den Pseudoclementinen," Philologus 93 (1938), 218-247; F. S. JONES, "The Pseudo-Clementines: A History of Research," Second Century 2 (1982), 1-33, 63-96; J. N. BrEmmer, ed., The Pseudo-Clementines, Studies on Early Christian Apocrypha 10 (Louvain 2010).

27 Eusebius, Praep. ev. 6.10.1-48, ed. K. Mras / É. Des Places, Eusebius, Werke VIII.1, second edition, GCS (Berlin 1982), 335,1-343,15.

${ }^{28}$ Synoptic printing of all three texts in REHM / STRECKER, Psendoklementinen II, 270-317.

${ }^{29}$ This question need not be taken up here. See the extensive discussion by REHM, "Bardesanes in den Pseudoclementinen." That the Book of the Laws originally was composed in Syriac (and not in Greek) has been argued convincingly by Th. NÖLDEKE, "Zum 'Buch der Gesetze der Länder'," ZDMG 64 (1910), 555-560. See also F. NAU, "Notes d'astronomie syrienne," Journal Asiatique, 10th series, vol. 16 (1910), 209228, esp. 216-219; G. LEVI DELLA VIDA, “Appunti Bardesanici,” Rivista degli studi orientali 8 (1919-1920), 709-722. 
discourse, ${ }^{30}$ in the Praeparatio evangelica he treats the excerpts from Bardaisan among the non-Christian refutations of astrology $^{31}$ - perhaps because in his Greek Vorlage, unlike in the extant Syriac version, Bardaisan does not explicitly identify himself as a Christian. ${ }^{32}$ The church historian first quotes a segment in which Bardaisan outlines the respective powers of nature and free will (BLC 15-16) and then produces a long pas-

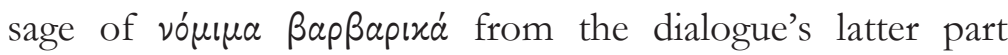
(BLC 25-47)..$^{33}$ For understanding the dissemination of Bardaisan's dialogue it is vitally important to note that Eusebius unlike the Ps.-Clementine Recognitions - cites from two separate sections of the Book of the Laws. Eusebius thus had access to the entire dialogue, whereas the author of the Ps.-Clementine Recognitions reveals familiarity only with the second, ethnographic part of this work.

The famous Antiochene exegete Diodore of Tarsus (d. ca. 390) takes up the subject of fate and free will in his xatà

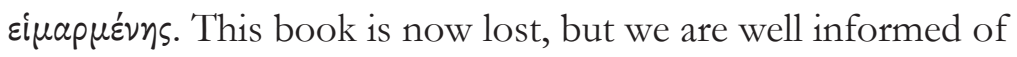
its arguments through the summary provided by the ninthcentury Constantinopolitan patriarch Photios in his Library. ${ }^{34}$

${ }^{30}$ Eusebius, h.e. 4.30, ed. Schwartz / Mommsen, 392,14-28.

${ }^{31}$ Eusebius, Praep. ev. 6.9.32 (ed. Mras / DES Places 334,20-24), introduces the quotation from Bardaisan by stating that now he will produce the arguments of the astrologers against the Chaldeans. In Praep. ev. 6.10.49 (ed. ibid., 343,17-20), he indicates that the discussion of non-Christian authors is now concluded and that he will move on to Christian authors. In fact, Origen comes next.

${ }^{32}$ In the Syriac dialogue, Bardaisan says, "what shall we say, then, about the new race of us Christians?" (

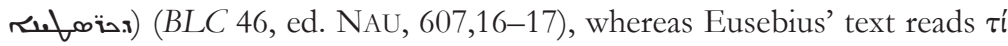

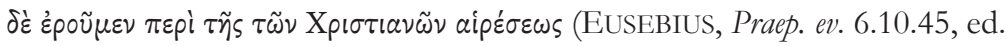
MRAS / DES PLACES, 342,23-24).

${ }^{33}$ BLC 15-16 and 25-47, ed. NAU, 558,10-562,3; 582,5-610,7.

34 Photios, Bibl. 223 (208b-222a), ed. R. Henry, Photius, Bibliothèque, vol. 4 (Paris 1991), 8-48. 
Right at the beginning of his synopsis, Photios favorably comments that Diodore (whose theology he apparently generally does not much appreciate) set forth a clear and zealous refutation of Bardaisan's doctrines in the fifty-first chapter of his treatise. According to the patriarch, Diodore began this section by summarily criticizing Bardaisan's position as a half-hearted compromise, because his discourse freed the soul from fate but kept the body and all which concerns it subject to fate. ${ }^{35}$ It is likely that Diodore regarded Bardaisan's coherent and wellargued position as a particular threat to his own anthropology and therefore wished to raise objections to it already at the beginning of his treatise On Fate. Bardaisan's theology apparently was still a force to be reckoned with at the end of the fourth century. After surveying Diodore's refutation, Photios in due course rehearses several specific points brought forth by the Antiochene exegete against Bardaisan. Diodore challenged Bardaisan's theory on biblical, theological, and philosophical grounds. ${ }^{36}$ Much of Diodore's reasoning against fate elsewhere in this treatise rests on anti-deterministic arguments in the tradition of Carneades, which, of course, were also employed by Bardaisan. ${ }^{37}$ Interestingly, certain parallels between Diodore and the Book of the Laws are apparent, ${ }^{38}$ so that the question

35 Photios, Bibl. 223 (208b), ed. Henry, 8,18-9,32.

36 Photios, Bibl. 223 (221b-222a), ed. Henry, 45,12-47,16.

${ }^{37}$ Cf. E. AMAND DE MENDIETA, Fatalisme et liberté dans l'antiquité grecque. Recherches sur la survivance de l'argumentation morale antifataliste de Carnéade chez. les philosophes grecs et les théologiens chrétiens des quatre premiers siècles (Louvain 1945). On Bardaisan's notion of fate and its relation to Alexander of Aphrodisias, see A. DiHLE, "Zur Schicksalslehre des Bardesanes," in: Kerygma und Logos. Beiträge $₹ u$ den geistesgeschichtlichen Beziehungen zwischen Antike und Christentum. Festschrift für Carl Andresen zum 70. Geburtstag, edited by A. M. RITTER (Göttingen 1979), 123-135.

${ }^{38}$ For instance, in 215b Diodore stresses that unlike the behavior of various animals, human action exhibits much variety, so that it consequently cannot possibly be determined by fate (ed. HENRY, 28,6-29,28). In 218a Diodore refers to the customs of Jews and Christians as counter examples (ed. HENRY, 35,13-36,33). 
presents itself to what degree Diodore might have mined his opponent's dialogue for those kinds of arguments that well suited his agenda.

The reception history of Bardaisan's Book of the Laws continues well into Byzantine times. In the sixth century, an anonymous author attributed certain theological dialogues to Caesarius, the brother of Gregory of Nazianzus, and these treatises show familiarity with the Book of the Laws. ${ }^{39}$ In the ninth century, the historian George Harmatolos quotes from the Book of the Laws. ${ }^{40}$ But inasmuch as George mentions Caesarius directly prior to his discussion of Bardaisan, and since the two passages contain many parallels, it appears likely that George may have derived his knowledge from Ps.-Caesarius, as already A. Hilgenfeld surmised. ${ }^{41}$ Finally, a reference to Bardaisan occurs in the Ecclesiastical History composed by Nikephoros Kallistos in the early part of the fourteenth century. ${ }^{42}$ Much of what Nikephoros writes about the Edessene is taken directly at times even verbatim - from Eusebius' Ecclesiastical History, but his account also includes an interesting detail that remains without parallel in the Greek patristic literature, ${ }^{43}$ so that one is led to wonder if, perhaps, he was acquainted with some of Bardaisan's treatises.

39 Ps.-CAesarius, Erotapokriseis, ed. R. RIEDINGER, Pseudo-Kaisarios, Die Erotapokriseis, GCS (Berlin 1989), 83-87. Older ed. in PG 38 (1862), 977-987 (= dial. 2, 109-110). On this author, see R. Riedinger, PseudoKaisarios. Überlieferungsgeschichte und Verfasserfrage, Byzantinisches Archiv 12 (München 1969). Brief overview in D. RAMOS-LISSÓN, "Pseudo-Caesarius," LThK 8 (1999), 708.

40 George Hamartolos, ed. J. A. Cramer, Anecdota Graeca Bibliothecarum Oxoniensium, vol. 4 (Oxford 1837, reprint Amsterdam 1963), 236-237. Brief overview of George in A. KAZHDAN / A. CUTLER, "George Hamartolos," Oxford Dictionary of Byzantium 2 (1991), 836.

${ }^{41}$ A. Hilgenfeld, Bardesanes, der letzte Gnostiker (Leipzig 1864), 93.

${ }^{42}$ Nikephoros Kaldistos, h.e. 4.11, PG 145 (1904), 1001.

${ }^{43}$ Noteworthy is Nikephoros' statement in the dialogue that Bardaisan characterized the "Father of the Logos" (PG 145, 1001). However, the section in Nikephoros is only brief and no definite conclusions can be drawn from it. 
Of all of Bardaisan's works, the Book of the Laws clearly is the one with the most significant impact upon late antique Christianity. Although Bardaisan was often criticized for entering a compromise on the subject of fate and thereby ceding too much to the power of the stars, the arguments set forth in his dialogue favorably impressed later generations of theologians and provided useful resources for the ongoing refutation of astral determinism. Yet Bardaisan's influence upon Christian thought, especially in his native Syriac tradition, far exceeds his reflections on fate and free will and pertains to many other areas as well. Some of these will be outlined in the remainder of this essay.

\section{Poetry and Madrashe}

The Syriac Christian tradition is rightly famous for its abundance of imaginative religious poetry, a feature that has characterized it from its inception. What constitutes perhaps the oldest extant literary text in Syriac, the Odes of Solomon, is a collection of hymns. ${ }^{44}$ The Acts of Thomas, dating to the early third century, incorporate poetic material. And Bardaisan, too, wrote hymns and psalms - one hundred and fifty of them in imitation of the psalms of David, Ephrem claims. Ephrem speaks of Bardaisan as a composer of both hymns (rix) and psalms (Rdirs $),{ }^{45}$ and his remarks suggest that in the Syriac world it was Bardaisan who first set the previously existing literary genre of madrasha to music. ${ }^{46}$ Bardaisan's son is said to have

44 Odes of Solomon, ed. J. H. CHARLESwOrTH, The Odes of Solomon. The Syriac texts, edited with translation and notes, SBL Texts and Translations 13, Pseudepigrapha 7 (Chico, CA 1977); also ed. with German transl. M. LATTKE, Oden Salomos. Text, Übersetzung, Kommentar, 3 vols., Novum Testamentum et Orbis Antiquus 41 (Göttingen 1999-2005). Scholarly opinion varies as to the date and original language of the Odes.

45 Ephrem, CH 53,5-6; 54,1, ed. Beck, 203,5-14; 204,25-205,3.

${ }^{46}$ EPhrem, CH 53,5, ed. Beck, 203,5-9. See K. E. MCVEY, "Were the Earliest Madrašè Songs or Recitations?" in: After Bardaisan. Studies on Continuity and Change in Syriac Christianity in Honour of Professor Han J. W. Drijvers, 
continued in the footsteps of his father and to have composed chants. ${ }^{47}$ These Bardaisanite madrashe significantly influenced the Syriac tradition, for Ephrem in the later fourth century laments that Bardaisan's followers still chant these hymns with their altogether objectionable content. ${ }^{48}$ According to the fifthcentury Greek church historians Sozomen and Theodoret, Ephrem consequently set out himself to compose madrashe with orthodox content, so that the tunes championed by Bardaisan and his son could now be sung without causing doctrinal offense. ${ }^{49}$ Bardaisan, even if he cannot be credited with having invented the genre of madrasha, appears to have been the earliest among the Syriac Christians to enhance this poetic form with music. He was a pioneer in setting poetry to music, and he did so with great and long-lasting success. From Ephrem's comments and the few extant fragments of Bardaisan's poetry, we can gather that certain of his hymns had educational theological content, discussing, for example, the doctrine of creation. ${ }^{50}$ Thereby Bardaisan's hymns constitute the oldest Syriac madrashe (a term derived from $d r s$, 'to instruct') that have come down to us, 'teaching-songs' in the true meaning of the word.

ed. G. J. REININK / A. C. KLUGKIST, OLA 89 (Louvain 1999), 185-199, esp. 187-190.

${ }^{47}$ EPHrEm, PR II, 221. See also the passages in Sozomen and Theodoret, cited below in n. 49.

${ }^{48}$ EPHREM, CH 1,17, ed. Beck, 5,1-3.

${ }^{49}$ Sozomen, h.e. 3.16.5-7; ed. J. BIDEz / G. C. HANSEN, Sozomenus, Kirchengeschicbte, second edition, GCS N.F. 4 (Berlin 1995), 128,15-129,8; TheOdoret, h.e. 4.29.2-3, ed. L. PARMentier / G. C. Hansen, Theodoret, Kirchengeschichte, third edition, GCS N.F. 5 (Berlin 1998), 269,13-18.

${ }^{50} \mathrm{H}$. H. SCHAEDER argued that the heresiological summary by Theodore bar Koni contains excerpts from Bardaisan's writings, cf. H. H. SCHAEDER, "Bardesanes von Edessa in der Überlieferung der griechischen und der syrischen Kirche," ZKG 51 (1932), 21-73, esp. 47-49. In CH 55, Ephrem quotes fragments of hymns attributed to Bardaisan's followers. These fragments seem to relate a cosmogonic myth. 
Some of Bardaisan's theological poems were apparently not only popular but also sufficiently orthodox to become disconnected from their author's name and to enter the mainstream of the Syriac tradition. In the late fifth century, Philoxenus of Mabbug and the deacon Habbib engaged in a literary controversy on christology, in the course of which Philoxenus articulated his own miaphysite stance as follows:

And the Ancient of Ages became a child, and the Most High a baby in the womb, and God became human in the womb, and the spiritual (became) bodily. ${ }^{51}$

The well-read Habbib ${ }^{52}$ claimed at once to have recognized the phrase "the Ancient of Ages became a child, and God a baby in the womb" as originating from none other than Bardaisan, and he lost no time in accusing Philoxenus of borrowing from a heretic. ${ }^{53}$ Philoxenus' own defense against Habbib's accusation is rather weak and gives the impression that Bardaisan indeed was the author of this metric passage. ${ }^{54}$ This episode illustrates the power and persuasiveness that Bardaisan's poetry exerted for centuries to come.

\section{Astronomy}

Bardaisan declares in the Book of the Laws that formerly he himself had belonged to the Chaldeans, that is to the astrologers

51 PhILOXENus, Letter to the Monasteries, ed. M. BRIERE / F. GRAFFIN, Dissertationes decem de uno et sancto Trinitate incorporate et passo, PO 41.1 (1982), 44,10-12.

${ }^{52}$ See Habbib's own statement, quoted by Philoxenus in Diss. 3,12, ed. BriÈre / GrAFFIN, PO 38.3, 486,4-6; cf. VAN ROMPAY, "Bardaisan and Mani," 81. On Philoxenus' objections to Habbib's reading list, see Diss. 10, 189-190, ed. BrIÈrE / GRAFFIN, PO 40.2 (1980), 344-346.

53 Philoxenus, Diss., ed. Brière / GrafFin, PO 41.1, Paris 1982, 14,27-16,2 (no. 17); cf. PO 41.1, 16,23-24 (no. 22); Diss. 1, 35, ed. BriÈrE, PO 15.4 (1920), 464,11-12.

${ }^{54} \mathrm{On}$ the details of the debate between Philoxenus and Habbib, see VAN ROMPAY, "Bardaisan and Mani." 
whose teachings he now so effectively opposes. ${ }^{55}$ After his conversion to Christianity, he outright rejected the central tenets of astral determinism and upheld human freedom in ethical matters. ${ }^{56}$ As is well known, astrology and astronomy went hand in hand in antiquity and one cannot always clearly distinguish between the two. And while Bardaisan's counterarguments in the Book of the Laws reveal his easy familiarity with astrological doctrines (which he now opposes), other texts demonstrate that he was also well acquainted with astronomy.

It may come as a surprise to realize that, in fact, later Syriac Christians admired him for his specialized astronomical knowledge and upheld his scientific inquiry as exemplary. In the seventh century, Severus Sebokht, the learned bishop and monk at Qenneshre, ${ }^{57}$ proudly points out that Bardaisan's astronomical insights undeniably demonstrate that not only pagans but also Syriac Christians were well versed in this discipline. ${ }^{58}$ In the eighth century, George, the bishop of the Arab tribes (d. 724), similarly takes recourse to the astronomical calculations of the Bardaisanites in a letter addressed to the stylite John of Litharb who had, among other things, inquired about

${ }^{5}$ BLC 16, ed. NAU, 564,19-23.

${ }^{56}$ Bardaisan upheld that astral phenomena can have some influence over factors that are beyond the control of human beings or the laws of nature, such as sickness or poverty that do occur but are generally undesired. This proposition made him unacceptable to the later normative church.

${ }^{57}$ On the intellectual life in the monastery, see J. TANNOUS, "You Are What You Read: Qenneshre and the Miaphysite Church in the Seventh Century," in: History and Identity in the Late Antique Near East, edited by PH. WOOD (Oxford 2013), 83-102. On Severus at Qenneshre, see É. VILLEY, "Qennešre et l'astronomie aux VIe et VIIe siècles," in: Les sciences en syriaque, edited by É. VILLEY, Études syriaques 11 (Paris 2014), 149-190.

58 NAU, "Notes d'astronomie syrienne," 211,20-212,1. See also E. REICH, "Ein Brief des Severus Sēboōknt," in: Sic itur ad astra. Studien zur Geschichte der Mathematik und Naturwissenschaften. Festschrift für den Arabisten Paul Kunitzsch zum 70. Geburtstag, ed. M. FOLKERTS / R. LORCH (Wiesbaden 2000), 478-489. 
the rising times of the zodiacal signs. ${ }^{59}$ Precise knowledge of the rising times was important for astrology, but it also allowed one to calculate the length of day and night for a particular date. Christians most likely were interested in such computations in order to determine the date of moveable feasts such as Easter. ${ }^{60}$ Significantly, Bishop George here endorses Bardaisan's scientific accomplishments as a solid base for calculations of astral phenomena, and he does not at all associate him with astrology. This is not due, as one might surmise, to George not being able adequately to distinguish between astronomy and astrology, for in another letter to the same John of Litharb, George vehemently rejects the claims of the "demonic astrologers." ${ }^{\prime 61}$ A further illustration of Bardaisan's astronomical interest comes from a short manuscript notice on the names for the zodiacal signs as they were used by the Bardaisanites. ${ }^{62}$ This brief segment is preserved in the same manuscript as is the Book of the Laws, but it does not immediately follow upon the dialogue. ${ }^{63}$ As with the rising times, the signs of the zodiac were certainly relevant to astrology, but they were occasionally also discussed by Christian intellectuals for their

${ }^{59}$ George, ep. 1 (dated 714 AD), ed. V. RYsSEL, "Die astronomischen Briefe Georgs des Araberbischofs," Zeitschrift für Assyriologie 8 (1893), 1-55, esp. 19,7-20,11. To be precise, George refers not to Bardaisan, but to the "Bardaisanites." The scientific background and relevance of the particular astronomical topics that are discussed by George and by Severus Sebokht need not be addressed here. For this, see the relevant sections in my forthcoming monograph on Bardaisan.

${ }^{60}$ Cf. GeOrGE, ep. 1, ed. Ryssel, "Die astronomischen Briefe," 8-11.

${ }^{61}$ GeOrGE, ep. 2 (dated 716), ed. RYSSEL, "Die astronomischen Briefe," 24-25.

${ }^{62}$ Ed. E. SACHAU, Inedita syriaca. Eine Sammlung syrischer Übersetzungen von Schriften griechischer Profanliteratur. Mit einem Anhang. Aus den Handschriften des Britischen Museums herausgegeben (Wien 1870, reprint Hildesheim 1968), 126.

${ }^{63}$ In the manuscript BL Syr. add. 14658, the Book of the Laws (the eleventh text in this manuscript) is followed by a treatise by Sergius of Resh 'aina On the Motion of the Moon and a short appendix thereto (On the Motion of the Sun), then follows the notice on the names of the signs of the zodiac; cf. Wright, Catalogue, vol. 3, 1158. 
scientific relevance, as the letter by George, the bishop of the Arab tribes, illustrates. ${ }^{64}$

These various testimonies show that Bardaisan was known and appreciated by later Syriac Christians for his astronomical insights and helpful calculations. We can thus concur with the view voiced already by François Nau more than a hundred years ago, based on his reading of two of the above-mentioned sources: "Les deux textes nous montrent encore que les préoccupations de Bardesane étaient d'ordre astronomique et géographique et n'avaient aucun rapport avec les fantaisies théurgiques que les auteurs postérieurs lui ont attribuées en l'adjoignant à Manès." 65

\section{ETHNOGRAPHY}

Bardaisan's broad ethnographic interest becomes quickly apparent to the reader of the Book of the Laws, for in the dialogue he reports at length on the various customs and rituals of other peoples. Both the sources employed by him and the later reception history of the diverse ethnographic material compiled in this treatise merit further research. Here, however, I should like to confine myself to some remarks on Bardaisan's interest in Indian culture and religion.

In the Book of the Laws, Indian customs play an important role and are mentioned in several passages. Bardaisan begins his list of the laws of the countries, presented in the second half of the treatise, with the Seres and then immediately moves on to the Indians. He describes the norms of life common among the ascetic Brahmans as well as the lifestyle of those who are not Brahmans. ${ }^{66}$ Later on in the dialogue he again takes up the customs of the Indians, now elaborating on their

${ }^{64}$ On the terminology for the signs of the zodiac used by George, see his letter to John of Litharb, ed. RYSSEL, 19-21. This is the same passage in which George discusses the rising times of the signs of the zodiac.

${ }^{65}$ F. NAU, "La cosmographie au VIIe siècle chez les Syriens," Revue de l'Orient Chrétien 15 (1910), 225-254, quote on p. 227.

${ }^{66}$ BLC 27-28, ed. NAU, 583,27-584,25. 
funerary rites. ${ }^{67}$ Moreover, the large territory of India serves him as a suitable example to show that within one climate zone a variety of customs can exist side by side, thus repudiating the Chaldean doctrine that one of the planets rules over each of the seven climata. $^{68}$

Bardaisan's curiosity about India led him to engage with an Indian delegation which he encountered, probably in Edessa, while they passed through the region en route to Emperor Elagabalus (218-222). In his writings he rehearses some of what he had learned from them, and fragments of his reflections on India have come down to us through the Neo-Platonist philosopher Porphyry (d. 305). In his treatise On the Styx, Porphyry preserves a passage from Bardaisan in which the Edessene describes an ordeal by water common among the Brahmans. In the same treatise, Porphyry presents another excerpt in which Bardaisan describes an androgynous cosmogonic statue, as it were a prototype of creation, that is said to be located in a grotto in India. In this cave, Brahmans purportedly assemble for prayer, debate the statue's meaning, and undergo a ritual of self-examination. ${ }^{69}$ Porphyry's interest in Bardaisan's work on India becomes evident also in his treatise On Abstinence, where he cites a lengthy passage from Bardaisan that describes the customs of the Indian Brahmans and of the

${ }^{67}$ BLC 39, ed. Nau, 596,13-20; BLC 40, ed. Nau, 599,4-8.

${ }^{68}$ BLC 42, ed. NAU, 600,22-26. On the theory of seven climata, see E.

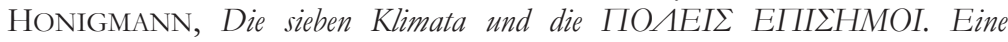
Untersuchung zur Geschichte der Geographie und Astrologie im Altertum und Mittelalter (Heidelberg 1929).

${ }^{69}$ POrPhyry, De Styge (= STOBAios, Florilegium. 1.3.56), ed. F. JACOBY, FGH 3C (Leiden 1958), no. 719, Fragm. 1, p. 643-645. Ed. with German transl. F. WINTER, Bardesanes von Edessa über Indien. Ein früher syrischer Theologe schreibt über ein fremdes Land, Frühes Christentum. Forschungen und Perspektiven 5 (Thaur 1999), 37-40, 47-55. For the most recent discussion of these fragments, see the excellent study by I. TANASEANU-DÖBLER, "Bemerkungen zu Porphyrios und Bardaișan," ZAC 19 (2015), 26-68. 
'Samaneans" ${ }^{70}$ (the latter of which are to be identified with Buddhist monks). ${ }^{71}$ Via Porphyry's works Bardaisan's ethnographic observations became available to a wider audience, including late antique Christian authors. Jerome, for instance, in his Against Jovinian takes over directly from Porphyry illustrative examples of how various pagan and Jewish groups practice asceticism, and he includes the striking illustration pertaining to India provided by Bardaisan. ${ }^{72}$

We do not know how far-reaching the influence of Bardaisan's ethnographic discourses was in late antiquity, but the examples shown above make manifest that his reflections on India certainly enjoyed a wider audience. Several passages were favorably cited by the pagan intellectual Porphyry, and Jerome's Against Jovinian reveals that Bardaisan's observations on foreign cultures were well received by patristic authors as well.

\section{COSMOLOGY}

Bardaisan's cosmology, which does not seem to have had much of an afterlife among Greek intellectuals, constitutes the aspect of his oeuvre most controversial among later Syriac authors. Although the Book of the Laws offers only a sketchy picture of Bardaisan's cosmology, it nevertheless clearly affirms that Bardaisan believed God to be the creator of the world and humankind. ${ }^{73}$ Regarding the heavenly bodies, Bardaisan maintains in the dialogue that these, too, are created entities and subject to the divine commandments. ${ }^{74} \mathrm{He}$ posits that the

${ }^{70}$ Porphyry, De abst. 4.17, ed. JACOBY, FGH 3C, no. 719, Fragm. 2, p. 645-647. Ed. with German transl. WinTER, Bardesanes, 41-43, 56-62. Engl. transl. T. TAYLOR, Porphyry, On Abstinence from Animal Food (London 1965).

71 Winter, Bardesanes, 141-142 and passim; TANASEANU-DÖBLER, "Bemerkungen," 59-60.

72 Jerome, Against Jovinian 2.14, PL 23, 304. Close textual analysis shows that it is unlikely that Jerome drew on Bardaisan's works directly.

${ }^{73}$ BLC 1, ed. NAU, 536,11-14; BLC 19, ed. NAU, 567,24-568,1.

${ }^{74}$ BLC 19, ed. Nau, 567,26-568,6; BLC 8, ed. Nau, 544,14-24. 
heavenly bodies were endowed with a certain kind of freedom - a view resonating with the statement in Gen. 1:17 according to which the heavenly bodies were given power to rule over day and night ${ }^{75}$ - and that based on the use they make of their freedom, they too will be judged on the last day. ${ }^{76}$ This understanding of the heavenly bodies in some respects resembles the ideas articulated by Origen in On First Principles, who likewise maintains that the heavenly bodies are rational beings endowed with free will. ${ }^{77}$ One cannot be sure whether this constitutes an instance of Bardaisan's influence upon the great Alexandrian theologian, or if any similarities between the thought of the Edessene and Origen - of which there are more - arise out of them reflecting upon the same questions and on the same biblical passages within a very similar cultural milieu.

The Book of the Laws hints at Bardaisan's belief that the world was created out of pre-existing substances, ${ }^{78}$ a notion not without parallel among early Christian writers. Justin Martyr, for instance, upheld the view that the world was made from

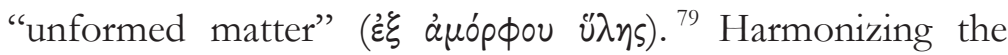

${ }^{75}$ Another biblical passage that might have motivated Bardaisan to this statement is Isa. 45:12, where God exclaims, "I have given commandments to all the stars." This verse is among biblical passages cited by Origen in support of his view that the heavenly bodies are rational beings. ORIGEN, De princ. 1.7.3, ed. KoETSCHAU, 88,11-12. On Bardaisan's use of Scripture more broadly, see my forthcoming article "Bardaisan and the Bible." See also A. CAMPLANI, "Bardaisan and the Bible," in: Gnose et manichéisme: entre les oasis d'Egypte et la route de la soie: hommage à Jean-Daniel Dubois, edited by A. VAn Den Kerchove / G. SOARES SANTOPRETE (Turnhout 2017), 699-715.

${ }^{76}$ BLC 9, ed. NAU, 548,15-19.

77 Origen, De princ. 1.7.2-1.7.3, ed. Koetschau. On this subject, see my "Bardaisan and Origen on Fate and the Power of the Stars," JECS 20 (2012), 515-541. Possible parallels between the thought of Bardaisan and Origen are also addressed by I. RAMELLI, "Origen, Bardaișan, and the Origin of Universal Salvation,”HTR 102 (2009), 135-168.

${ }^{78}$ BLC 8, ed. NAU, 547,10-12; BLC 46, ed. NAU, 611,10-15.

${ }^{79}$ Justin, 1 Apol. 10.2, ed. M. MARCOVICH, Iustini Martyris Apologiae pro Christianis, PTS 38 (Berlin 1994), 45,7. 
accounts given by Plato in the Timaeus and by Moses in Genesis 1:2, Justin elaborates: "So by God's word the whole universe was made out of this substratum ( $\dot{x} \tau \tilde{\omega} \nu$ i $\pi \circ x \varepsilon \mu \varepsilon \dot{\varepsilon} \nu \omega \nu$ ), as expounded by Moses, and Plato and those who agree with him, as well as we, have learned it [from him]." ${ }^{80}$ Hermogenes (fl. 175-205) ${ }^{81}$ too interprets the Genesis account of creation, not unlike Bardaisan, in such a way that led him to postulate the existence of several uncreated primal elements (darkness, the abyss, the spirit, and water). ${ }^{82}$ In the second century, when Bardaisan formulated his cosmology, a belief in pre-existing substances was thus held by several Christian intellectuals, but in a later age, when the doctrine of a creatio ex nibilo had emerged as a broad consensus among theologians, ${ }^{83}$ the

80 Justin, 1 Apol. 59, ed. Marcovich, 115,10-11; transl. C. C. RiCHARDSON, Early Christian Fathers (New York 1970), 280.

${ }^{81}$ M. DuRst, "Hermogenes," LThK 5 (1996), 13.

82 Tertullian, Adversus Hermogenem 23.1, 30.1, 41-43, and passim, ed. F. CHApot, Tertullien, Contre Hermogène, SC 439 (Paris 1999), 140-142, 158160, 188-194. On Hermogenes and his teachings, see K. GRESCHAT, Apelles und Hermogenes. Zwei theologische Lehrer des zweiten Jabrhunderts, Vigiliae Christianae Supplements 48 (Leiden 2000), esp. 148-166, 224f. Brief outline of Bardaisan's cosmogony in my "Die Schöpfungstheologie des Bardaisan von Edessa," in: Edessa in hellenistisch-römischer Zeit. Religion, Kultur und Politik zwischen Ost und West. Beiträge des internationalen Edessa-Symposiums in Halle an der Saale, 14.-17. Juli 2005, ed. L. GREISIGER / C. RAMMELT / J. TUBACH, Beiruter Texte und Studien 116 (Beirut 2009), 219-229; see also A. CAMPlani, "Note bardesanitiche," Miscellanea Marciana 12 (1997), 1143; A. Camplani, "Rivisitando Bardesane: Note sulle fonti siriache del bardesanismo e sulla sua collocazione storico-religiosa," Cristianesimo nella storia 19 (1998), 519-596; A. CAMPLANI, "Bardesane et bardésanites," École pratique des hautes études. Section des sciences religieuses Annuaire. Résumé des conférences et travaux 112 (2003-2004), 29-50 (includes discussion of an unedited fragment on Bardaisan's cosmogony in the Hexaemeron commentary by Moses bar Kepha).

83 See the comprehensive study by G. MAY, Schöpfung aus dem Nichts. Die Entstehung der Lehre von der creatio ex nibilo, Arbeiten zur Kirchengeschichte 48 (Berlin 1978). On Jewish discussions of the subject, see M. R. NiEHOfF, "Creatio ex Nibilo Theology in Genesis Rabbah in Light of Christian Exegesis," HTR 99 (2005), 37-64; M. KISTER, "Tohu wa- 
presupposition of some sort of primordial matter came to be regarded as an outrageous heresy. The fact that Bardaisan's followers continued to uphold the idea of primordial matter and that, moreover, they appear to have developed his doctrines further into a dualist direction, ${ }^{84}$ relegated them to a place far outside the mainline tradition.

This process can be illustrated by the shifting role attributed to the darkness in the Bardaisanite cosmogony. The Book of the Laws, in which the creation of the world receives some attention, never even mentions the darkness. In the Syriac dialogue Bardaisan firmly rejects dualist notions, ${ }^{85}$ and this makes it highly unlikely that he would have regarded the darkness as some kind of evil entity. On the other hand, since it can be shown that Bardaisan, as a Christian theologian, developed his cosmogony in light of the Genesis account, it would be surprising that the darkness (which features so prominently in Gen 1:2-5) should not have received some attention in his creation theology. It is thus quite plausible, as Ephrem later maintained, that the darkness constituted for Bardaisan one of the primordial elements (alongside water, wind, light, and fire), ${ }^{86}$ although it is highly doubtful that he would have considered the darkness as an evil entity, standing in opposition to God. While Ephrem generally does not characterize Bardaisan's

Bohu, Primordial Elements and Creatio ex Nihilo," Jewish Studies Quarterly 14 (2007), 229-256. On the Syriac Christian interpretation of Gen. 1:2, see A. Guillaumont, "Genèse 1,1-2 selon les commentateurs syriaques," in: In Principio. Interprétations des premiers versets de la Genèse, Collections des Études Augustiniennes. Série Antiquité 38 (Paris 1973), 115-132; S. Brock, "The Ruah Elōhim of Gen 1,2 and its Reception History in the Syriac Tradition," in: Lectures et relectures de la Bible. Festschrift P.-M. Bogaert, ed. J.-M. AuWERS / A. WÉNIN, Bibliotheca Ephemeridum Theologicarum Lovaniensium 144 (Louvain 1999), 327-349.

${ }^{84}$ See EPHREM, PR II, 227,2-6.

${ }^{85}$ BLC 1, ed. NAU, 536,11-12.

${ }^{86}$ EPHREM, PR I, 52-53; II, 222-225. 
darkness as evil, he hints at this idea when he calls darkness 'ugly' (1) in the Hyms against Heresies. ${ }^{87}$

One may surmise that under Manichaean influence Bardaisan's disciples radicalized his teachings and increasingly conceptualized darkness as a negative force, so that by the sixth century mainline Syriac Christian authors could describe the darkness in the Bardaisanite cosmology as 'the enemy'

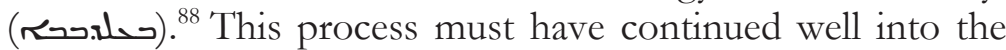
Islamic era, for Arabic authors generally treat the Bardaisanites among the dualist sects and claim that they proposed a juxtaposition of light and darkness within the cosmogonic system. ${ }^{89}$

Bardaisan's thought in general, and his cosmology in particular, must have exercised a profound influence upon the formation of the Manichaean doctrinal system. The fact that Mani, just as had Bardaisan before him, composed a book entitled On the Mysteries already hints at a certain rivalry. ${ }^{90} \mathrm{Ibn}$ al-Nadim in his Fibrist reports that in his Book of Mysteries Mani dedicated three sections to a refutation of Bardaisan's teachings. ${ }^{91}$ Moreover, the Arabic astronomer and scientist al-Biruni (973-1048) preserves a quotation from Mani's treatise On the Mysteries, in which Mani explicitly opposes certain of Bardaisan's views. ${ }^{92}$ Mani's letter to the Edessenes, of which the

${ }^{87}$ EPHrEm, CH 41,7, ed. Beck, 166,9-13. The passage implies that the attribute "ugly" (or "hateful") is Ephrem's and not Bardaisan's terminology.

88 BarHadbeshabBa 'Arbaia, History 2.5, ed. NAU, 191,8.

${ }^{89}$ See the literature cited in $\mathrm{n} .12$ above.

${ }^{90}$ Bardaisan's treatise On the Mysteries is mentioned by EPHREM, $\mathrm{CH}$ 56,9; cf. CH 1,14. On Mani's book of the same title see the following footnote.

${ }^{91}$ AL-NADIM, Fibrist 9.1, transl. DoDGE, vol. 2, 797f. It is of course possible that further sections of this book also addressed Bardaisan's teachings.

${ }^{2}$ The passage is ed. E. SACHAU, Alberuni's India. An account of the religion, philosophy, literature, geography, chronology, astronomy, customs, laws and astrology of India about A.D. 1030, 2 vols. (London 1888), transl. in vol. 1, 54-55. The subject here is the relation between human soul and body. On this source, 
Cologne Mani Codex preserves an excerpt, confirms that a group of Mani's followers resided in Edessa. ${ }^{93}$ In light of such close contacts, it would not come as a surprise to find later followers of Bardaisan in conversation with Manichaeans, adapting their own cosmological views to those of this successful new religious movement, and in turn influenced it as well.

\section{THE REFUTATION OF MARCIONISM}

A further aspect of Bardaisan's reception among late antique Christians that ought to be mentioned here is his refutation of Marcionism. ${ }^{94}$ As W. Bauer has shown long ago, the Marcionites established a community in Edessa at a very early time,

see A. CAmplani, "Bardaisan’s Psychology: Known and Unknown Testimonies and Current Scholarly Perspectives," in: Syriac Encounters: Papers from the Sixth North American Syriac Symposium, Duke University, 26-29 June 2011, edited by M. DOERFLER / E. FIANO / K. SMITH (Leuven 2015), 259-276. On the relation between Bardaisan's thought and the Manichaean system, a subject still deserving further study, see for example H. J. W. DRIJVERS, "Mani und Bardaișan. Ein Beitrag zur Vorgeschichte des Manichäismus," in: Mélanges d'histoire des religions offerts à Henri-Charles Puech (Paris 1974), 459469; B. Aland, "Mani und Bardesanes - Zur Entstehung des manichäischen Systems," in: Synkretismus im syrisch-persischen Kulturgebiet. Bericht über ein Symposium in Reinhausen bei Göttingen in der Zeit vom 4. bis 8. Oktober 1971, ed. A. DiETRICH, Abhandlungen der Akademie der Wissenschaften in Göttingen. Philologisch-historische Klasse, dritte Folge, Nr. 96 (Göttingen 1975), 123-143; S. N. C. LIEU, Manichaeism in the Later Roman Empire and Medieval China. A Historical Survey (Manchester 1985), 4245, 103-104; G. HARrison / J. BEDuHN, "The Authenticity and Doctrine of (Ps.?) Mani's Letter to Menoch," in: The Light and the Darkness. Studies in Manichaeism and its World, edited by P. MIRECKI / J. BEDUHN (Leiden 2001), 128-172, esp. 151-153, 168-171 (on the possible impact of the BLC on the author of this letter).

${ }^{93}$ Cologne Mani Codex 64,8-65,22, ed. with German transl. L. KOENEN / C. RÖMER, Der Kölner Mani-Kodex. Über das Werden seines Leibes (Opladen 1988), 44f.; ed. with Engl. transl. R. CAMERON / A. J. DEWEY, The Cologne Mani Codex (P. Colon. inv. nr. 4780): Concerning the Origin of his Body (Missoula, Mont. 1979), 50-53.

${ }^{4}$ On Marcion, see now J. LIEU, Marcion and the Making of a Heretic: God and Scripture in the Second Century (Cambridge, UK 2015). 
perhaps even preceding the arrival of 'orthodox' Christianity, ${ }^{95}$ so that Bardaisan most certainly was confronted with the controversial teachings of Marcion and his followers. Bardaisan's vehement opposition to Marcion's theology constitutes one of the best documented aspects of his activity, ${ }^{96}$ but unfortunately none of his dialogues against the Marcionites has survived ${ }^{97}$ and only traces of his anti-Marcionite reasoning remain in the patristic literature. In the Book of the Laws, Bardaisan affirms the doctrine of the oneness and goodness of God, an indication that he here specifically targets, albeit without explicitly mentioning the name, Marcion's novel distinction between a good god and a foreign god. ${ }^{98}$ Further evidence for Bardaisan's consistent opposition to Marcion is supplied by the Life of Aberkios, the second-century bishop of Hierapolis in Phrygia whose vita was composed in the fourth century. ${ }^{99}$ Aberkios on

${ }^{95} \mathrm{~W}$. BAUER, Orthodoxy and Heresy in Earliest Christianity (Mifflintown, PA 1996), first publ. as Recbtgläubigkeit und Ketzerei im ältesten Cbristentum, 1934.

${ }^{96}$ The BLC does not explicitly mention Marcion, but Bardaisan's initial arguments refute the Marcionite postulate of two gods. Eusebius, Ephrem, the Life of Aberkios, and the Adamantius Dialogue (ed. W. H van den Sande Bakhuyzen, Der Dialog des Adamantius, GCS [Leipzig 1901]), all mention Bardaisan's anti-Marcionite efforts as well. Hippolytus, Ref. VII 31,1, refers to a treatise by the Marcionite Prepon against Bardaisan, thus confirming the existence of a literary debate between Marcionites and Bardaisan, ed. M. MARCOVICH, Hippolytus. Refutatio omnium baeresium, PTS 25 (Berlin 1986), $312,3-5$.

${ }^{97}$ Such dialogues are mentioned by EuSEBIUS, h.e. 4.30.1-2, ed. SCHWARTZ / MOMMSEN, 392,14-23.

${ }_{98}^{8}$ BLC 1-2, ed. NAU, 536,9-539,4.

${ }^{99}$ On the date of the Vita Abercii, see D. Bundy, "The Life of Abercius: Its Significance for Early Syriac Christianity," Second Century 7 (1989-90), 163-176; P. THONEMANn, "Abercius of Hierapolis: Christianization and Social Memory in Late Antique Asia Minor," in: Historical and Religious Memory in the Ancient World, edited by B. Dignas / R. R. R. Smith. (Oxford 2012), 257-282. 
his travels purportedly met Bardaisan. ${ }^{100}$ The bishop is also said to have encountered a certain Marcionite named Euxenianos and to have engaged him in a lively debate during which Aberkios conveniently drew on Bardaisan's speeches in the Book of the Laws. ${ }^{101}$

Even Ephrem the Syrian, Bardaisan's most vocal antagonist, cannot but acknowledge Bardaisan's persuasive refutation of Marcionism. ${ }^{102}$ Among other arguments, Bardaisan apparently adduced philosophical considerations on the nature of space in order to challenge Marcion's notion of two gods, though unfortunately the precise ductus of Bardaisan's reasoning can no longer be accessed on account of the fragmentary nature of our sources. Ephrem on the one hand tries to undermine Bardaisan's premises on space in order to challenge Bardaisan's cosmology; ${ }^{103}$ but elsewhere Ephrem's refutation of Marcion reveals such similarity with Bardaisan's arguments that in the end, the reader of Ephrem's hymns is left to wonder to what extent his anti-Marcionite polemic is itself indebted to the apologetic discourses of his great Edessene rival. ${ }^{104}$

\section{The AlphaBet of BARDAISAN}

A curiosity in the reception history of Bardaisan is the so-called 'alphabet of Bardaisan', a cipher widely used by Syriac scribes to encrypt words, usually their own name, but at times also

100 Life of Aberkios 69-70, ed. NISSEN, 48,17-50,8. French transl. now in P. Maraval, Vie d'Abercius. Vie de Polycarpe. Deux biographies légendaires d'évêques du Ile siècle (Paris 2017).

101 Life of Aberkios 31-38, ed. NisSEN, 23-30. Detailed discussion of the parallels between the Vita Abercii and the Book of the Laws by Th. NISSEN, "Die Petrusakten und ein bardesanitischer Dialog in der Aberkiosvita," ZNW 9 (1908), 190-203, 315-328. See also H. GRÉGOIRE, "Bardesane et S. Abercius," Byzantion 25-27 (1955-1957), 363-368.

102 Ephrem repeatedly affirms that Bardaisan criticized Marcion, e.g., EPHREM, CH 3,4; PR I, 135.

103 EPHREM, PR I, 135f.; cf. CH 3,4.

104 See for example EPHREM, CH 32,14; 35,1-4. 
other short texts. These are normally found in manuscript colophons. This cipher was first noted by Wright and commented upon by some nineteenth-century scholars, but only recently has it garnered more attention. ${ }^{105}$ The encryption takes place by permutating the letters of the alphabet according to the following schema. ${ }^{106}$

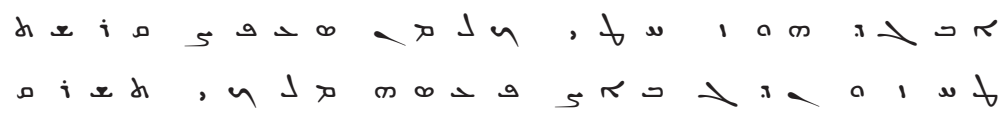

Several manuscripts, ranging in date from the $14^{\text {th }}$ through the $19^{\text {th }}$ century, spell out this alphabet, occasionally alongside other alphabets or ciphers; this particular code (with some minor variations) is consistently named 'alphabet of Bardaisan'. ${ }^{107}$ The cipher is not unique to the Syriac world; similar ciphers occur in rabbinic literature as well as in Greek and Coptic texts. It originated in Greek, where the earliest extant evidence is a graffito from the second century, and was then adapted from

105 WRIGHT, Catalogue ... British Museum, vol. 3, 1207 and passim; B. H. COWPER, "The Alphabet of Bardaisan," Journal of Sacred Literature and Biblical Record 6 (1863), 465-466; A. MERX, Bardesanes von Edessa, nebst einer Untersucbung über das Verbältnis der clementinischen Recognitionen zu dem Buche der Gesetze der Länder (Halle 1863), 61-62, n. 1; R. DuVAL, Traité de grammaire syriaque: écriture, phonétique, orthographie, les parties du discours et les formes des mots, syntaxe, index des mots (Paris 1881), 12-13; Y. PAZ / T. WeIss, "From Encoding to Decoding: The ATTBH of R. Hiyya in Light of a Syriac, Greek and Coptic Cipher," Journal of Near Eastern Studies 74 (2015), 45-65.

${ }^{106}$ BL add. 7202. The scribe here lists assorted other alphabets in conjunction with that of Bardaisan. See WRIGHT, Catalogue, vol. 3, 1207, who however does not here list the alphabet of Bardaisan. For this, see J. P. N. LAND, Anecdota syriaca (Leiden 1886), 13; PAZ / WeISS, "From Encoding to Decoding," 52.

${ }^{107}$ A slight variation is found in the subscription of ms. BL add. 21,211, fol. 146b, see Wright, Catalogue, vol. 3, 1182. The date of this ms. is AD 1831 (fol. 42b, see Wright, Catalogue, vol. 3, 1181). 
the Greek by Coptic and Syriac scribes. ${ }^{108}$ A peculiarity of this code is that when the numerical value of each letter is added to that of its code letter, the sum amounts to $10,100,55$, or $500 .{ }^{109}$ This numerological aspect, however, is not normally commented upon by Syriac scribes. Although the actual code and its designation as 'alphabet of Bardaisan' appears only in later manuscripts, scribes employed it already in some of our oldest extant Syriac manuscripts (dating to the first half of the sixth century). ${ }^{110}$

The question of whether one can attribute this cipher with some confidence to the historical Bardaisan must be asked, and while it cannot be answered with certainty, I should like here to present some reasons that might suggest a cautiously positive response. ${ }^{111}$ While it is true, as Paz and Weiss have observed, that the earliest evidence for the cipher in Syriac "dates to more than three centuries after Bardaisan's death" and the designation 'alphabet of Bardaisan' appears only in later manuscripts, ${ }^{112}$ we must emphasize that the use of the

108 See the detailed study by PAZ / WeISs, "From Encoding to Decoding." On the second-century graffito from Egypt, see ibid., 58-59.

${ }^{109}$ For details, and the corresponding Greek numerological analysis, see PAZ / WEISS, "From Encoding to Decoding." The first to draw attention to this was COWPER, "Alphabet."

${ }^{110} \mathrm{BL}$ add. 17,176 (containing Palladius) is dated AD 532, and the encoded name of Stephen appears on fol. $87 \mathrm{~b}$, according to Wright written in "[a]nother, but still ancient, hand" (WRIGHT, Catalogue, vol. 3, 1072-1073). The codex BL add. 14,431 contains the books of Samuel in the Peshitta version and was collated in AD 545 by a certain George who wrote his name in this cipher (WRIGHT, Catalogue, vol. 1, 14-15).

111 COWPER, "Alphabet," left the question open and suggested a "Gnostic origin" (466). DuVAL, Traité de grammaire, 13, posited that the Syriacs received the cipher from the Jews and attributed it to Bardaisan as "le premier et le plus célèbre des gnostiques de la Syrie."

112 PAZ / WEISS, "From Encoding to Decoding," 58. Because of this, and since no evidence exists that Bardaisan himself or his followers used the cipher, they do not consider it likely that the cipher originated with Bardaisan (51-52). However, in light of the very fragmentary nature of the 
cipher was a scribal habit documented in some of our oldest Syriac manuscripts; it was not a subject discussed by ancient Syriac authors. The earliest evidence of this alphabet comes from colophons dating from the first half of the sixth century, thus belonging to the oldest layer of Syriac manuscripts since only very few manuscripts produced prior to this date have come down to us. ${ }^{113}$ Moreover, drawing attention to the fact that this cipher originated with the ill-reputed Bardaisan surely lay not in the interest of any ancient scribe. Nor do these early scribes, in fact, ever spell out the code or its name; only rather later manuscripts contain references to the actual cipher and its name, 'alphabet of Bardaisan'. Three further points can be adduced in support of the hypothesis that this alphabet may have originated with Bardaisan. First, Julius Africanus - whom Bardaisan met in person - is known to have appreciated codifications and quite possibly employed this particular cipher. ${ }^{114}$ It is thus conceivable that Bardaisan learned the code from Africanus. Second, Bardaisan is known to have exhibited interest in numbers, ${ }^{115}$ and he was fascinated with language and the meaning of words. ${ }^{116}$ Adopting this cipher from the Greek to Syriac would hence fit his intellectual profile precisely. And

sources on Bardaisan, an argument ex silentio does not carry too much weight.

113 See S. Brock, "A Tentative Check List of Dated Syriac Manuscripts up to 1300.“ Hugoye 15.1 (2012), 21-48. Brock lists only fifteen manuscripts prior to 532 .

114 JUlius AFriCANUS, Kestoi 7. 6, ed. WALlRAFF et al., 58-61. The documentary evidence is somewhat inconclusive, and Paz and Weiss seem to waiver as to whether or no Africanus knew the cipher. However, the persuasive arguments in their Appendix suggest that he may well have been familiar with it. (PAZ / WEISS, "From Encoding to Decoding," 65).

115 This is clear from the astrological calculations with which later writers credit him. He also engaged in experiments intended to ascertain how far an arrow would fly if it were to travel at an equal speed for 24 hours. See Julius AFricanus, Kestoi 7.20, ed. WALlRAFF et al. 98-101.

116 On the names for the signs of the zodiac, see above n. 62. On Bardaisan's interest in names more generally, see EPHREM, PR II, 48 and 221222. 
thirdly, it would be difficult to explain, were he not at all affiliated with the origin of this Syriac code, why it should have been named after him - a contemptible heretic, after all, in the eyes of most Syriac scribes (as they do not fail to point out). ${ }^{117}$

The alphabet of Bardaisan enjoyed a surprisingly wide and long-lasting reception. Babylonian Jews adapted the code from the Syriac, and the ATTBH cipher had a long afterlife in Jewish literature. ${ }^{118}$ Interestingly, rabbis would occasionally even employ the cipher to decode a biblical word; ${ }^{119}$ a midrash draws on the numerical aspect of the code; and Kabbalistic literature enhances with the cipher its theosophical discourse. ${ }^{120}$ In the Syriac tradition, by contrast, the numerological aspect recedes into the background and the principal application of the alphabet lies in encoding a scribe's name, a short phrase, or a brief text. ${ }^{121}$ One scribe even enhanced his encrypted request for prayer by a pictorial representation of the encoded letters. ${ }^{122}$ The practice was seemingly ubiquitous: colophons with encoded words are found in East and West Syriac manuscripts from as early as A.D. 545 to as recent as the nineteenth century, and range in content from New Testament Gospels to saints' lives, from grammar treatises and lexica to philosophical handbooks. $^{123}$

117 The scribe of Vat. sir. 96, fol. 159a, writes out the alphabet and labels it "the alphabet of Bardaisan the wicked, which he and his wicked troop used."

118 PAZ / WEISS, "From Encoding to Decoding," 48-51.

${ }^{119}$ R. Hiyya employed the cipher to explain the hapax manon (Prov. 29:21), see PAZ / WEISS, "From Encoding to Decoding," 45-46.

120 PAZ / WEISS, "From Encoding to Decoding," 48-51.

121 The scribe of BL add. 14,606, an $8^{\text {th }}$-century codex containing spiritual and monastic literature, wrote a short encoded paragraph in the colophon; see Wright, Catalogue, vol. 2, 744-745.

${ }^{122}$ Cambridge Or. 1142 , fol. 324v (Barhebraeus, Ethicon, ms. dated 18 ${ }^{\text {th }}$ cent.; see J. F. COAKLEY, A Catalogue of the Syriac Manuscripts in Cambridge University Library and College Libraries Acquired since 1901 (2018), 60-61.

${ }^{123}$ See for example Cambridge Oo.1.31, fol. 220b (Gospels and Epistles, East Syriac, ca. $17^{\text {th }}$ to $18^{\text {th }}$ cent.; see W. WrighT, $A$ Catalogue of the Syriac Manuscripts Preserved in the Library of the University of Cambridge, vol. 2 


\section{CONCLUSION}

Just as only traces remain from Bardaisan's numerous works, so we can find only hints in the patristic literature about the impact these have had on the church of late antiquity. Yet the evidence that does survive unequivocally shows the far-reaching and powerful influence this original thinker exercised upon subsequent generations. Although Bardaisan was later considered a dangerous heretic, his most influential work, the Book of the Laws, was read, used, and criticized by generations of Greek patristic theologians, and it appears to have had an afterlife in the Syriac tradition as well. Its clever anti-deterministic arguments offered convenient tools for those wishing to refute astrology, and its numerous ethnographic illustrations could easily be adapted to other purposes. By setting madrashe to music, Bardaisan made an innovation of considerable importance. His madrashe inspired Ephrem, as Sozomen relates, to write his own teaching hymns that in turn would transform Syriac literature. Bardaisan's cosmology, perhaps not so exceptional in his own time as later opponents claim, but further radicalized by his later followers, continued to challenge the Syriac church and significantly contributed to the negative image passed down by Syriac authors of Bardaisan the heresiarch. Bardaisan's objections to Marcion's thought are well documented, and although but little survives of his reasoning, it appears plausible that his

[Cambridge 1901], 1109-1110); BL 14,431, fol. 157a (Book of Samuel according to the Peshitta version, dated AD 545; see WrIGHT, Catalogue, vol. 1, 14-15); BL add. 21,21, fol. 145a (encoded text), 145b (alphabet of Bardaisan) (the manuscript contains an elementary grammar and the metrical grammar of Bar Hebraeus and is dated AD 1831 (fol. 42b); see WRIGHT, Catalogue, vol. 3, 1180-1182); Berlin Syriac ms. 90 (philosophical terms; ms. dating to the $17^{\text {th }}$ cent.; see E. SACHAU, Verzeichniss der syrischen Handschriften der Königlichen Bibliothek zu Berlin, vol. 1 (Berlin 1899), 338-339. Further examples can be adduced, and I hope soon to offer a more comprehensive analysis of this scribal habit in Syriac manuscripts. 
Dialogues against the Marcionites provided Ephrem with a convenient starting-point for his own anti-Marcionite polemics. ${ }^{124}$ Later generations of Syriac authors also admired Bardaisan's scientific accomplishments that ranged from astronomical calculations to experiments on the flight of arrows. His personal acquaintance with Julius Africanus provides a tangible link with Graeco-Roman culture, and it may have been this encounter that inspired Bardaisan to adapt the Greek cipher to the Syriac language. If the attribution of the alphabet to Bardaisan is correct, this may well constitute his longest-lasting legacy.

\section{BIBLIOGRAPHY}

\section{Primary Sources}

Adamantius Dialogue. Ed. W. H. VAN DE SANDE BAKHUYZEN. Der Dialog des Adamantius. GCS 4 (Leipzig 1901).

BarHadbešHabBa 'Arbaia. History. Ed. F. NAu. La première partie de l' Histoire de Barbadbešabba 'Arbaïa. Texte syriaque édité et traduit. PO 23.2 (Paris 1932).

AL-BIRUNI. On India. Ed. with English transl. E. SACHAU. Alberuni's India. An account of the religion, philosophy, literature, geography, chronology, astronomy, customs, laws and astrology of India about A.D. 1030. 2 vols. (London 1888).

Ps.-CAESARIUS. Erotapokriseis. Ed. R. RIEDINGER. Pseudo-Kaisarios, Die Erotapokriseis. GCS (Berlin 1989).

Ps.-Clement. Homilies. Ed. B. Rehm / G. Strecker. Die Pseudoklementinen I. Homilien. GCS (Berlin 1992).

124 Some of this research was presented several years ago at a workshop entitled "Bardesanes - Liber legum regionum," held at Göttingen University. I would like to thank the organizers, and especially Dr. Ilaria Ramelli, for the invitation to attend. I am also grateful to the colloquium participants and to Dr. Lucas van Rompay for their comments on an earlier version of this article. 
Ps.-Clement. Recognitions. Ed. B. ReHM / G. StRecker. Die Pseudoklementinen II: Rekognitionen in Rufins Übersetzung. Second edition. GCS (Berlin 1994).

Ps.-Clementines [Syriac version]. Ed. W. FrankenBerg. Die syrischen Clementinen mit griechischem Paralleltext. TU 48/3 (Leipzig 1937).

Ps.-Clementines. English transl. F. S. JONES. The Syriac PseudoClementines. An Early Version of the First Christian Novel (Turnhout 2014).

Cologne Mani Codex. Ed. with German transl. L. KoEnen / C. RÖMER. Der Kölner Mani-Kodex. Über das Werden seines Leibes (Opladen 1988).

Cologne Mani Codex. Engl. Transl. R. CAmeron / A. J. Dewey. The Cologne Mani Codex (P. Colon. inv. nr. 4780). Concerning the Origin of his Body (Missoula, Mont. 1979).

Didymus THE Blind. Commentary on the Psalms. Ed. A. GESCHÉ / M. Gronewald. Didymus der Blinde, Psalmenkommentar (Tura-Papyrus). Vol. 3 (Bonn 1969).

EPHREM. Hymns against Heresies. Ed. with German transl. E. BECK. Ephraem des Syrers Hymnen contra haereses. CSCO 169-170 / Syr. 76-77 (Louvain 1957).

EPHrem. Hymns on Nisibis. Ed. with German transl. E. BECK. Des heiligen Ephraem des Syrers Carmina Nisibena. CSCO 218 219 / Syr. 92-93 (Louvain 1961-1963).

Ephrem. Prose Refutations. Ed. with English transl. C. W. Mitchell / A. A. Bevan / F. C. BurkitT. S. Ephraim's Prose Refutations of Mani, Marcion, and Bardaisan. 2 vols. (London 1912-1921).

EPIPHAnIUs. Panarion. Ed. K. Holl. Epiphanius, Werke II. GCS (Leipzig 1922). 
EpIPhanius. Panarion. Transl. F. Williams. The Panarion of Epiphanius of Salamis. Books II and III (Sects 47-80, De Fide). Nag Hammadi and Manichaean Studies 36 (Leiden 1994).

Eusebius of CAesarea. Historia ecclesiastica. Ed. E. SchWARTZ / TH. Mommsen. Eusebius, Werke II.1. Die Kirchengeschichte. Second edition. GCS N.F. 6.1 (Berlin 1999).

Eusebius of CAESAREA. Historia ecclesiastica [Syriac version]. Ed. W. Wright / N. MCLEAN. The Ecclesiastical History of Eusebius in Syriac, edited from the manuscripts. With a collation of the Armenian version by Adalbert Merx (Cambridge 1898).

Eusebius of Caesarea. Praeparatio evangelica. Ed. K. Mras / É. DES PlaCES. Eusebius, Werke VIII.1. Second edition. GCS (Berlin 1982).

Eusebius of Emesa. Commentary on Genesis. Ed. F. Petit / L. VAN Rompay / J. J. S. WEITENBERG. Eusèbe d'Émèse, Commentaire de la Genèse. Texte arménien de l'édition de Venise (1980). Fragments grecs et syriaques. Avec traductions. Traditio Exegetica Graeca 15 (Louvain 2011).

GeOrge, Bishop of THE ARABs. Letters. Ed. with German transl. V. RYSSEL. "Die astronomischen Briefe Georgs des Araberbischofs." Zeitschrift für Assyriologie 8 (1893), 1-55.

George Hamartolos. History. Ed. J. A. Cramer. Anecdota Graeca Bibliothecarum Oxoniensium. Vol. 4 (Oxford 1837, reprint Amsterdam 1963).

Hippolytus. Refutatio omnium haeresium. Ed. M. MARCOVICH. Hippolytus. Refutatio omnium haeresium. PTS 25 (Berlin 1986).

JaCob of EDESSA. Hexaemeron. Ed. I.-B. СНAвOT. Iacobi Edesseni Hexaemeron. CSCO 92 / Syr. 44 (Louvain 1953).

JACOB OF EDESSA. Hexaemeron. Latin transl. A. VASCHALDE. Iacobi Edesseni Hexaemeron. CSCO 97 / Syr. 48 (Louvain 1953). 
Jacoby, F. Die Fragmente der griechischen Historiker, Dritter Teil, C (Leiden 1958).

Jerome. De viris illustribus. Ed. E. C. RICHARDSON. Hieronymus, Liber de viris inlustribus. Gennadius, Liber de viris inlustribus. TU 14.1 (Leipzig 1896).

JEROME. Against Jovinian. PL 23 (1845), 211-338.

Julius Africanus. Kestoi. Ed. and transl. M. Wallraff / C. Scardino / L. Mecella / Ch. Guignard / W. Adler. Cesti: The Extant Fragments. GCS N.F. 18 (Berlin 2012).

Justin. 1 Apologia. Ed. M. Marcovich. Iustini Martyris Apologiae pro Christianis. PTS 38 (Berlin 1994).

Justin. 1 Apologia. Transl. C. C. RiChardson, Early Christian Fathers (New York 1970).

Life of Aberkios. Ed. TH. Nissen. S. Abercii Vita (Leipzig 1912). Life of Aberkios. French transl. P. Maraval. Vie d'Abercius. Vie de Polycarpe. Deux biographies légendaires d'évêques du IIe siècle (Paris 2017).

Ps.-Meliton. Apology. Ed. with English transl. W. Cureton. Spicilegium Syriacum: containing remains of Bardesan, Meliton, Ambrose and Mara bar Serapion (London 1855), 22-31 (text), 41-51 (transl.).

Michael the Syrian. Chronicle. Ed. with French transl. J.-B. Снавот. Chronique de Michel le Syrien. 4 vols. (Paris 18991910, reprint Brussels 1963).

Moses BAR KePHA. Hexaemeron Commentary. Transl. L. SCHLIMME. Der Hexaemeronkommentar des Moses bar Kepha. Einleitung, Übersetzung und Untersuchungen. 2 vols. Göttinger Orientforschungen, 1. Reihe: Syriaca, vol. 14.1-2 (Wiesbaden 1977).

AL-NADIM, IBN. Fibrist. Ed. G. FLÜGEL (Leipzig 1871-1872). 
AL-NAdim, IBN. Fibrist. Transl. B. Dodge. The Fibrist of alNadim. A Tenth-Century Survey of Muslim Culture. 2 vols. (New York 1970).

Nikephoros Kaldistos. Historia ecclesiastica. PG 145 (1904), 549-1332.

Odes of Solomon. Ed. with German transl. M. LATTKE. Oden Salomos. Text, Übersetæung, Kommentar. 3 vols. Novum Testamentum et Orbis Antiquus 41 (Göttingen 1999-2005).

Odes of Solomon. Ed. with English transl. J. H. CHARLESWORTH. The Odes of Solomon. The Syriac texts, edited with translation and notes. SBL Texts and Translations 13, Pseudepigrapha Series 7 (Chico, CA 1977).

Origen. De principiis. Ed. P. Koetschau. Origenes, Werke V. De principiis. GCS (Leipzig 1913).

Philoxenus of MabBug. Dissertationes decem de uno et sancto Trinitate incorporate et passo. Ed. M. BRIERE / F. GRAFFIN. PO 15.4, 38.3, 39.4, 40.2, 41.1 (Paris 1920-1982).

Photios. Bibliotheca. Ed. R. Henry. Photius, Bibliothèque. Vol. 4: Codices 223-229 (Paris 1991).

POrPhyry. De abstinentia. Transl. Th. TAYLOR. Porphyry, On Abstinence from Animal Food (London 1965).

Sozomen. Historia ecclesiastica. Ed. J. BIDEZ / G. C. HANSEN. Sozomenus, Kirchengeschichte. Second edition. GCS N.F. 4 (Berlin 1995).

Tertullian. Adversus Hermogenem. Ed. with French transl. F. Снарот. Tertullien, Contre Hermogène. SC 439 (Paris, 1999).

Theodore Bar Koni. Scholion. Ed. A. Scher. Theodorus bar Kōni, Liber scholiorum II. CSCO 66 / Syr. 26 (Louvain 1912).

TheOdORE BAR KONI. Scholion. Transl. R. HesPel / R. DRAguet. Théodore bar Koni, Livre des scolies (recension de 
Séert) II. Mimrè VI-XI. CSCO 432 / Syr. 188 (Louvain 1982).

TheOdoret OF Kyros. Historia ecclesiastica. Ed. L. Parmentier / G. C. HANSEN. Theodoret, Kirchengeschichte. Third edition. GCS N.F. 5 (Berlin 1998).

\section{Secondary Sources}

Aland, B. "Mani und Bardesanes - Zur Entstehung des manichäischen Systems." In: Synkretismus im syrisch-persischen Kulturgebiet. Bericht über ein Symposium in Reinhausen bei Göttingen in der Zeit vom 4. bis 8. Oktober 1971, edited by A. DieTRICH (Göttingen 1975), 123-143.

Amand de Mendieta, E. Fatalisme et liberté dans l'antiquité grecque. Recherches sur la survivance de l'argumentation morale antifataliste de Carnéade chez les philosophes grecs et les théologiens chrétiens des quatre premiers siècles (Louvain 1945).

BAUER, W. Orthodoxy and Heresy in Earliest Christianity (Mifflintown, PA 1996). Originally published as Rechtgläubigkeit und Ketzerei im ältesten Christentum (Tübingen 1934).

BAUMSTARK, A. Geschichte der syrischen Literatur mit Ausschluß der christlich-palästinensischen Texte (Bonn 1922).

Bremmer, J. N., ed. The Pseudo-Clementines. Studies on Early Christian Apocrypha 10 (Louvain 2010).

Brock, S. "The Ruaḥ Elōhim of Gen 1,2 and its Reception History in the Syriac Tradition." In: Lectures et relectures de la Bible. Festschrift P.-M. Bogaert, edited by J.-M AuWERS / A. WÉNIN (Louvain 1999), 327-349.

Brock, S. "A Tentative Check List of Dated Syriac Manuscripts up to 1300.” Hugoye 15.1 (2012), 21-48.

Bundy, D. "The Life of Abercius: Its Significance for Early Syriac Christianity.” Second Century 7 (1989-90), 163-176. 
CAMPlani, A. "Bardesane et bardésanites." École pratique des hautes études. Section des sciences religieuses. Annuaire. Résumé des conférences et travaux 112 (2003-2004), 29-50.

CAMPlani, A. "Bardaisan and the Bible." In: Gnose et manichéisme: entre les oasis d'Egypte et la route de la soie: hommage à Jean-Daniel Dubois, edited by A. VAN DEN KerCHOvE / G. SOARES SANTOPRETE (Turnhout 2017), 699-715.

Camplani, A. "Bardaisan's Psychology: Known and Unknown Testimonies and Current Scholarly Perspectives." In: Syriac Encounters: Papers from the Sixth North American Syriac Symposium, Duke University, 26-29 June 2011, edited by M. Doerfler / E. Fiano / K. Smith (Leuven 2015), 259-276.

Camplani, A. "Note bardesanitiche." Miscellanea Marciana 12 (1997), 11-43.

Camplani, A. "Rivisitando Bardesane: Note sulle fonti siriache del bardesanismo e sulla sua collocazione storico-religiosa." Cristianesimo nella storia 19 (1998), 519-596.

COAKLEY, J. F. A Catalogue of the Syriac Manuscripts in Cambridge University Library and College Libraries Acquired since 1901 (2018).

COwper, B. H. “The Alphabet of Bardaisan," Journal of Sacred Literature and Biblical Record 6 (1863), 465-466.

DiHLE, A. "Zur Schicksalslehre des Bardesanes." In: Kerygma und Logos. Beiträge $z u$ den geistesgeschichtlichen Beriebungen zwischen Antike und Christentum. Festschrift für Carl Andresen zum 70. Geburtstag, edited by A. M. RITTER (Göttingen 1979), 123-135.

Drijvers, H. J. W. Bardaișan of Edessa. Studia Semitica Neerlandica 6 (Assen 1966).

Drijvers, H. J. W. "Mani und Bardaișan. Ein Beitrag zur Vorgeschichte des Manichäismus." In: Mélanges d'bistoire des religions offerts à Henri-Charles Puech (Paris 1974), 459-469. 
Durst, M. “Hermogenes.” LThK 5 (1996), 13.

Duval, R. Traité de grammaire syriaque: écriture, phonétique, orthographie, les parties du discours et les formes des mots, syntaxe, index des mots (Paris 1881).

Gregoire, H. "Bardesane et S. Abercius." Byzantion 25-27 (1955-1957), 363-368.

Greschat, K. Apelles und Hermogenes. Zwei theologische Lehrer des zweiten Jahrbunderts. Vigiliae Christianae Supplements 48 (Leiden 2000).

Guillaumont, A. "Genèse 1,1-2 selon les commentateurs syriaques." In: In Principio. Interprétations des premiers versets de la Genèse (Paris 1973), 115-132.

HaAr Romeny, R. B. Ter. A Syrian in Greek Dress. The Use of Greek, Hebrew, and Syriac Biblical Texts in Eusebius of Emesa's Commentary on Genesis. Traditio Exegetica Graeca 6 (Louvain 1997).

HARrison, G. / J. BEDuhn. "The Authenticity and Doctrine of (Ps.?) Mani's Letter to Menoch." In: The Light and the Darkness. Studies in Manichaeism and its World, edited by P. MiRECKI / J. BEDUHN (Leiden 2001), 128-172.

Hegedus, T. Early Christianity and Ancient Astrology (New York 2007).

Hilgenfeld, A. Bardesanes, der letzte Gnostiker (Leipzig 1864).

Honigmann, E. Die sieben Klimata und die $\Pi O \Lambda E I \Sigma$ EПIऽHMOI. Eine Untersuchung zur Geschichte der Geographie und Astrologie im Altertum und Mittelalter (Heidelberg 1929).

Jansma, T. Natuur, lot en vrijheid. Bardesanes, de filosoof der Arameeërs en rijn images. Cahiers bij het Nederlands theologisch tijdschrift 6 (Wageningen 1969).

Jones, F. S. "The Pseudo-Clementines: A History of Research.” Second Century 2 (1982), 1-33, 63-96. 
JuRASZ, I. “Éphrem, Bardesane et Albinus sur les Incorporels. Une confrontation entre le platonisme et le stoïcisme en milieu syriaque." Philosophie antique 17 (2017), 169-204.

JURASz, I. "Résurrection de l'âme chez Bardesane." Chora. Journal of Ancient and Medieval Studies 9-10 (2011-2012), 399427.

KAZHDAN, A. / A. CuTler. "George Hamartolos.” Oxford Dictionary of Byzantium 2 (1991), 836.

KInG, D. "Origenism in Sixth Century Syria: The Case of a Syriac Manuscript on Pagan Philosophy." In: Origenes und sein Erbe in Orient und Okzident, edited by A. FÜrST (Münster 2011), 179-212.

KISTER, M. "Tohu wa-Bohu, Primordial Elements and Creatio ex Nihilo.” Jewish Studies Quarterly 14 (2007), 229-256.

LAND, J. P. N. Anecdota syriaca (Leiden 1886).

LEVI DELLA VIDA, G. “Appunti Bardesanici.” Rivista degli studi orientali 8 (1919-1920), 709-722.

LiEU, J. Marcion and the Making of a Heretic: God and Scripture in the Second Century (Cambridge, UK 2015).

LIEU, S. N. C. Manichaeism in the Later Roman Empire and Medieval China. A Historical Survey (Manchester 1985).

Madelung, W. “Abū 'Īsā al-Warrāq über die Bardesaniten, Marcioniten und Kantäer." In: Studien zur Geschichte und Kultur des Vorderen Orients. Festschrift für Bertold Spuler zum siebrigsten Geburtstag, edited by H. R. ROEMER / A. NOTH (Leiden 1981), 210-224.

MAY, G. Schöpfung aus dem Nichts. Die Entstehung der Lebre von der creatio ex nibilo. Arbeiten zur Kirchengeschichte 48 (Berlin 1978).

MCVEy, K. E. "Were the Earliest Madraše Songs or Recitations?" In: After Bardaisan. Studies on Continuity and Change in 
Syriac Christianity in Honour of Professor Han J. W. Drijvers, edited by G. J. REININK / A. C. KLUGKIST. OLA 89 (Louvain 1999), 185-198.

MERX, A. Bardesanes von Edessa, nebst einer Untersuchung über das $V$ erbältnis der clementinischen Recognitionen zu dem Buche der Gesetze der Länder (Halle 1863).

MonnOt, G. Islam et religions. Islam d'hier et d'aujourd'hui 27 (Paris 1986).

NAU, F. "La cosmographie au VIIe siècle chez les Syriens." Revue de l'Orient Chrétien 15 (1910), 225-254.

NAU, F. "Notes d'astronomie syrienne." Journal Asiatique, $10^{\text {th }}$ series, vol. 16 (1910), 209-228.

NieHoff, M. R. "Creatio ex Nibilo Theology in Genesis Rabbah in Light of Christian Exegesis." HTR 99 (2005), 37-64.

Nissen, TH. "Die Petrusakten und ein bardesanitischer Dialog in der Aberkiosvita." ZNW 9 (1908), 190-203, 315-328.

NÖLDEKE, TH. “Zum 'Buch der Gesetze der Länder'.” ZDMG 64 (1910), 555-560.

PAZ, Y. / T. WEISs. "From Encoding to Decoding: The AṬBH of R. Hiyya in Light of a Syriac, Greek, and Coptic Cipher." Journal of Near Eastern Studies 74 (2015), 45-65.

Possekel, U. "Bardaisan and Origen on Fate and the Power of the Stars." JECS 20 (2012), 515-541.

PosseKel, U. "Die Schöpfungstheologie des Bardaisan von Edessa." In: Edessa in hellenistisch-römischer Zeit. Religion, Kultur und Politik zwischen Ost und West. Beiträge des internationalen Edessa-Symposiums in Halle an der Saale, 14.-17. Juli 2005, edited by L. Greisiger / C. RAMmelt / J. TUBACH. Beiruter Texte und Studien 116 (Beirut 2009), 219229. 
PosseKeL, U. "Bardaisan of Edessa on the Resurrection. Early Syriac Eschatology in its Religious-Historical Context." Oriens Christianus 88 (2004), 1-28.

RAMELLI, I. Bardaisan of Edessa. A Reassessment of the Evidence and a New Interpretation (Piscataway, NJ 2009).

RAMELLI, I. "Origen, Bardaișan, and the Origin of Universal Salvation.” HTR 102 (2009), 135-168.

RAmos-Lissón, D. "Pseudo-Caesarius.” LThK 8 (1999), 708.

ReHM, B. "Bardesanes in den Pseudoclementinen." Philologus 93 (1938), 218-247.

REICH, E. "Ein Brief des Severus Sēboōknt." In: Sic itur ad astra. Studien zur Geschichte der Mathematike und Naturwissenschaften. Festschrift für den Arabisten Paul Kunitzsch zum 70. Geburtstag, edited by M. FolKerTS / R. LORCH (Wiesbaden 2000), 478-489.

RIEDINGER, R. Pseudo-Kaisarios. Überlieferungsgeschichte und $V$ erfasserfrage. Byzantinisches Archiv 12 (München 1969).

SACHAU, E. Inedita syriaca. Eine Sammlung syrischer Übersetzungen von Schriften griechischer Profanliteratur. Mit einem Anhang. Aus den Handschriften des Britischen Museums herausgegeben (Wien 1870, reprint Hildesheim 1968).

SACHAU, E. Verzeichniss der syrischen Handschriften der Königlichen Bibliothek zu Berlin. 2 vols. (Berlin 1899).

SCHAEDER, H. H. "Bardesanes von Edessa in der Überlieferung der griechischen und der syrischen Kirche.” ZKG 51 (1932), 21-73.

TANASEAnU-DöBleR, I. "Bemerkungen zu Porphyrios und Bardaișan.” ZAC 19 (2015), 26-68.

TANnOUS, J. "You Are What You Read: Qenneshre and the Miaphysite Church in the Seventh Century." In: History and Identity in the Late Antique Near East, edited by PH. WOOD (Oxford 2013), 83-102. 
ThOnemann, P. “Abercius of Hierapolis: Christianization and Social Memory in Late Antique Asia Minor." In: Historical and Religious Memory in the Ancient World, edited by B. Dignas / R. R. R. Smith. (Oxford 2012), 257-282.

VAJDA, G. "Le témoigne de al-Māturidī sur la doctrine des Manichéens, des Dayṣānites et des Marcionites." Arabica 13 (1966), 1-38.

VAN Ess, J. Theologie und Gesellschaft im 2. und 3. Jahrhundert Hidschra. Eine Geschichte des religiösen Denkens im frühen Islam. 6 vols. (Berlin 1991-1995).

VAN ROMPAy, L. "Bardaisan and Mani in Philoxenus of Mabbog's Mèmrē Against Habbib.” In: Syriac Polemics. Studies in Honour of Gerrit Jan Reinink, edited by W. J. VAN BEKKUM / J. W. Drijvers / A. C. Klugkist. OLA 170 (Louvain 2007), 77-90.

VILLEY, É. "Qennešre et l'astronomie aux VIe et VIIe siècles." In: Les sciences en syriaque, edited by É. VILLEY. Études syriaques 11 (Paris 2014), 149-190.

WINTER, F. Bardesanes von Edessa über Indien. Ein früher syrischer Theologe schreibt über ein fremdes Land. Frühes Christentum. Forschungen und Perspektiven 5 (Thaur 1999).

Wright, W. Catalogue of the Syriac Manuscripts in the British Museum. 3 vols. (London 1870-1872).

Wright, W. A Catalogue of the Syriac Manuscripts Preserved in the Library of the University of Cambridge. 2 vols. (Cambridge 1901). 
